ELEMEN ESTETIS KOREOGRAFI TARI CANG-CANG DI KAYUAGUNG KABUPATEN OGAN KOMERING ILIR

Emy Admala Yuliarti

KONSEP KEBERSAMAAN DALAM TRADISI MIDANG MABANG HANDAK PADA MASYRAKAT MORGESIWE KECAMATAN KAYUAGUNG

A. Heryanto

PANGLIMA LAOQT SEBAGAI LOCAL WISDOM MASYARAKAT NELAYAN PESISIR ACEH (STUDI KASUS TENTANG PANGLIMA LAOQT LHOK KECAMATAN SERUWAY KABUPATEN ACEH TAMIANG)

Purnama Sari \& Puspitawati

PENERAPAN MODEL PEMBELAJARAN COURSE REVIEW HORAY TERHADAP KEMAMPUAN MENJELASKAN ALUR CERPEN UNTUK ANAK SDN 52 PALEMBANG Sri Wahyu indrawati

PENGARUH MODEL PEMBELAJARAN ARTIKULASI TERHADAP KEMAMPUAN MENULIS PADA SMP NEGERI 2 PALEMBANG

Yus Vernandes Uzer

PENGARUH MODEL PEMBELAJARAN COMPLETE SENTENCE TERHADAP KEMAMPUAN MENULIS PADA SMP NEGERI 13 PALEMBANG

Yuspar Uzer

$60-70$

PENGARUH MUSIK ANSAMBEL TERHADAP KECERDASAN EMOSI REMAJA

Novdaly Fillamenta \& Mohammad Arfani

PEWAISAN RABAB PIAMAN DI KECAMATAN LUBUK ALUNG

KABUPTEN PADANG PARIAMAN

Irfan Kurniawan

$82-93$

ESTETIKA MOTIF NAGO BESAUNG PADA KAIN SONGKET PALEMBANG Decky Kunian

BENTUK GERAK TARI KAIN DI SANGGAR DEWAN KESENIAN MUSI RAWAS

Pransiska Sepriyanti 


\title{
PENGARUH MODEL PEMBELAJARAN ARTIKULASI TERHADAP KEMAMPUAN MENULIS PADA SMP NEGERI 2 PALEMBANG
}

\author{
Oleh: \\ Yus Vernandes Uzer \\ (Dosen FKIP Univiversitas PGRI Palembang)
}

\begin{abstract}
Abstrak
Masalah dalam penelitian ini adalah bagaimanakah pengaruh model pembelajaran artikulasi terhadap kemampuan menuliskan kembali pokok-pokok berita yang didengarkan siswa Kelas VII SMP Negeri 2 Palembang. Tujuan penelitian ini untuk mengetahui dan mendeskripsikan pengaruh model pembelajaran artikulasi terhadap kemampuan menuliskan kembali pokok-pokok berita yang didengarkan siswa Kelas VII SMP Negeri 2 Palembang.Metode yang digunakan dalam penelitian ini adalah metode eksperimen dan teknik pengumpulan data dilakukan dengan teknik tes. Populasi dalam penelitian ini adalah seluruh siswa kelas VII yang berjumlah 130 siswa dan sampel dalam penelitian ini berjumlah 66 siswa yang terdiri atas dua kelas, yaitu kelas eksperimen berjumlah 34 siswa dan kelas kontrol berjumlah 32 siswa yang diambil menggunakan teknik random sampling. Berdasarkan hasil penelitian pada kesimpulan, dinyatakan bahwa menulis pokok berita kelas eksperimen yang diajarkan menggunakan model artikulasi lebih baik dari hasil belajar siswa kelas kontrol yang diajarkan dengan metode ceramah yang dilihat melalui pengujian hipotesis karena terbukti bahwa nilai $t_{\text {hitung }}$ lebih besar dari nilai $t_{\text {tabel }}$ sebesar 6,48 $>2,00$ atau dilihat dari nilai rata-rata kelas eksperimen 74,5 lebih besar dibandingkan nilai rata-rata kelas kontrol 63,1 . Hal tersebut menunjukkan adanya pengaruh model pembelajaran artikulasi terhadap hasil belajar siswa pada mata pelajaran Bahasa Indonesia pada materi menulis pokok-pokok berita siswa Kelas VII SMP Negeri 2 Palembang.
\end{abstract}

Kata Kunci: Model Pembelajaran Artikulasi, Kemampuan Menulis Pokok Berita

\section{A. PENDAHULUAN}

Pendidikan adalah usaha sadar yang dilakukan oleh keluarga, masyarakat, dan pemerintah, melalui kegiatan bimbingan, pengajaran, dan atau latihan, yang berlangsung disekolah dan diluar sekolah sepanjang hayat, untuk mempersiapkan peserta didik agar dapat memainkan peranan dalam berbagai lingkungan hidup secara tepat di masa yang akan datang (Mudyahardjo, 2012:11).
Belajar merupakan suatu proses yang dilakukan seseorang untuk memperoleh perubahan-perubahan dalam pengetahuan, pemahaman, atau keterampilan yang baru sebagai hasil pengalamannya sendiri dalam interaksi dengan lingkungannya.

Dalam kegiatan belajar mengajar, anak adalah sebagai subjek dan sebagai objek dari kegiatan pengajaran. Karena itu, inti proses pengajaran tidak lain adalah kegiatan belajar anak didik dalam mencapai 
suatu tujuan pengajaran. Tujuan pengajaran tentu saja akan dapat tercapai jika anak didik berusaha secara aktif untuk mencapainya. Dalam belajar ada anak didik yang cepat mencerna bahan, ada anak didik yang sedang mencerna bahan, dan ada pula anak didik yang lamban mencerna bahan yang diberikan oleh guru. Ketiga tipe belajar anak didik ini menghendaki agar guru mengatur strategi pengajarannya yang sesuai dengan gaya-gaya belajar anak didik (Djamarah dan Aswan Zain, 2013:38-39).

Kemampuan menulis merupakan salah satu aspek kemampuan bahasa yang harus dikuasai oleh siswa. Kebiasaan menulis dapat mengembangkan kemampuan berpikir dan meningkatkan pengetahuan siswa.

Menulis merupakan kegiatan seseorang untuk menyampaikan gagasan kepada pembaca dalam bahasa tulis agar bisa dipahami oleh pembaca. Kegiatan menulis sangat penting dalam pendidikan karena dapat membantu siswa berlatih berpikir, mengungkapkan gagasan, dan memecahkan masalah (Rosidi, 2009:2-3).

$$
\text { Berita merupakan informasi }
$$
mengenai suatu kejadian atau peristiwa yang sedang terjadi, baik disajikan lewat media cetak, siaran, atau internet. Dalam menuliskan kembali pokok-pokok berita atau unsur berita seseorang harus benar-benar memahami isi berita yang dibaca atau didengarkan. Chaer (2010:17-18), mengemukakan bahwa semua berita itu harus mengungkap unsur $5 \mathrm{~W}$ dan $1 \mathrm{H}$, yaitu what apa yang terjadi, who siapa yang terlibat dalam kejadian, why mengapa kejadian itu timbul, where dimana tempat kejadian itu, when kapan terjadinya, dan how bagaimana kejadiannya. Setiap berita harus mengandung keenam unsur itu dan fakta-faktanya.

Dalam proses belajar-mengajar sangat dituntut keaktifan siswa untuk mencapai hasil belajar yang baik. Jadi, dalam proses interaksi belajar-mengajar guru tidak hanya terpaku pada satu model saja, tetapi harus menggunakan model yang lain dengan tujuan agar proses belajar mengajar tidak membosankan dan bisa menarik perhatian anak didik. Untuk mengatasi masalah tersebut, guru harus berusaha membangkitkan semangat belajar siswa agar hasil belajarnya bisa lebih baik lagi.

Berdasarkan hasil observasi awal peneliti, penulis mendapat sejumlah permasalahan yang ditemukan di Kelas VII SMP Negeri 2 Palembang, yaitu proses belajar siswa yang bersifat pasif, siswa kebanyakan malas untuk belajar, tidak memperhatikan, malu bertanya, siswa hanya mencatat pada proses belajar 
mengajar, dan hanya menerima apa saja yang disampaikan oleh guru. Karena dalam sekolah ini guru masih menggunakan cara lama, yaitu menggunakan metode ceramah dan sampai saat ini masih sangat disukai oleh para guru di Kelas VII SMP Negeri 2 Palembang.

Sebagai guru harus menyadari apa yang sebaiknya dilakukan untuk menciptakan kondisi belajar mengajar yang dapat mengantarkan anak didik ke tujuan dan guru berusaha menciptakan suasana belajar yang menggairahkan dan menyenangkan bagi semua anak didik. Suasana belajar yang tidak menggairahkan dan menyenangkan bagi anak didik biasanya lebih banyak mendatangkan kegiatan belajar mengajar yang kurang harmonis. Salah satu model pembelajaran yang bisa digunakan agar poses belajar dapat berjalan dengan baik yaitu model pembelajaran artikulasi. Model pembelajaran artikulasi adalah model yang proses pembelajarannya siswa diminta untuk menyampaikan materi yang didapatkan dari guru kepada pasangannya secara bergiliran. Di dalam pasangan tersebut terdapat penyampai dan pendengar.

Penulis menetapkan menerapkan model artikulasi karena model pembelajaran artikulasi menuntut siswa untuk aktif dalam pembelajaran dan bisa menjadikan siswa lebih mandiri (Shoimin, 2014:27).

Menurut Joyce dikutip Ngalimun (2014:7) model pembelajaran adalah suatu perencanaan atau suatu pola yang digunakan sebagai pedoman dalam merencanakan pembelajaran di kelas atau pembelajaran dalam tutorial menentukan perangkat pembelajaran termasuk di dalamnya buku-buku, film, komputer, kurikulum, dan lain-lain.

Menurut Soekamto, dkk. dikutip Ngalimun (2014:8) bahwa model pembelajaran adalah kerangka konseptual yang melukiskan prosedur yang sistematis dalam mengorganisasikan pengalaman belajar untuk mencapai tujuan belajar tertentu dan berfungsi sebagai pedoman bagi para perancang pembelajaran dan para pengajar dalam merencanakan aktivitas belajar-mengajar.

Berdasarkan kedua pendapat di atas, dapat disimpulkan bahwa model pembelajaran adalah suatu perencanaan atau strategi yang digunakan sebagai pedoman oleh seorang guru dalam melaksanakan kegiatan belajar-mengajar agar tujuan yang ingin dikehendaki dapat tercapai.

Menurut Aqib (2015:17-36) macammacam model pembelajaran antara lain sebagai berikut. 
1) Examples Non-Examples (pembelajaran sesuai gambar yang relevan).

2) Picture and Picture (menekankan pada gambar).

3) Numbered Heads Together (pembagian nomor pada masingmasing siswa).

4) Cooperative Script (bekerja berpasangan).

5) Kepala Bernomor (mencocokkan berdasarkan nomor kelompok).

6) Student Teams Achievement Division (STAD) (evaluasi berdasarkan kelompok).

7) Jigsaw (model tim ahli atau kelompok ahli).

8) Probem Based Introduction (PBI) (pembelajaran berbasis masalah).

9) Artikulasi (pembelajaran berpasangan secara bergilir).

10) Mind Mapping (pembelajaran berdaasarkan alternatif jawaban).

11) Make a Match (mencari pasangan).

12) Think-Pair-Share (belajar berpikir, berbicara, dan menulis).

13) Debate (pembelajaraan konsep atau ide yang belum terungkap).

14) Role Playing (berdasarkan skenario yang disiapkan).

15) Group Investigation (pembelajaran kelompok yang bersifat penemuan).
16) Talking Stick (pembelajaran yang menggunakan tongkat sebagai alat belajar).

17) Bertukar Pasangan (saling bertukar pendapat dan pikiran).

18) Snowball Throwing (kertas yang berbentuk bola yang berisi pertanyaan).

19) Student Facilitator and Explaining (siswa saling menyampaikan pendapat).

20) Course Review Horay (berdasarkan arahan vouting).

21) Demonstration (peragaan atau percobaan).

22) Explicit Intruction (pembelajaran yang langsung/terstruktur).

23) Inside-Outside Circle (pembelajaran berbentuk lingkaran).

24) Tebak Kata (bermain tebak kata dengan kartu).

25) Word Square (jawaban dalam kotak).

26) Take and Give (memberi dan menerima).

27) Time Token (kupon berbicara).

28) Pair Checks (pelatih mengecek).

29) Keliling Kelompok (bertukar pikiran).

30) Tari Bambu (bertukar pikiran dan informasi).

31) Dua Tinggal Dua Tamu (saling bertukar pikiran). 
32) Pakem (aktif, kreatif, efektif, dan menyenangkan).

Menurut Shoimin (2014:27), model artikulasi merupakan model pembelajaran yang menuntut siswa untuk bisa berperan sebagai "penerima pesan" sekaligus sebagai "penyampai pesan". Pembelajaran yang telah diberikan guru, wajib diteruskan oleh siswa dan menjelaskannya kepada siswa lain di dalam pasangan kelompoknya. Model pembelajaran artikulasi sebagai suatu model pembelajaran yang menekankan pada kemampuan siswa untuk pandai berbicara atau menggunakan katakata dengan jelas, pengetahuan dan cara berpikir dalam penyampaian kembali materi yang telah disampaikan oleh guru. Model pembelajaran ini menuntut siswa aktif dalam pembelajaran, di mana siswa dibentuk menjadi kelompok kecil yang masingmasing siswa dalam kelompok tersebut mempunyai tugas mewawancarai teman kelompoknya tentang materi yang baru dibahas.

Menurut Huda (2014:269), model artikulasi merupakan model pembelajaran yang menuntut siswa aktif dalam pembelajaran. Pada pembelajaran ini, siswa dibagi ke dalam kelompok-kelompok kecil yang masing-masing anggotanya bertugas mewawancarai teman kelompoknya tentang materi yang baru dibahas. Skill pemahaman sangat diperlukan dalam metode pembelajaran ini.

Sementara menurut Ngalimun (2014:174), model artikulasi adalah model pembelajaran dengan sintaks (pola urutan), yaitu: penyampaian kompetensi, sajian materi, bentuk kelompok berpasangan sebangku, salah satu siswa menyampaikan materi yang baru diterima kepada pasangannya kemudian bergantian, presentasi di depan hasil diskusisnya, guru membimbing siswa untuk menyimpulkan.

Berdasarkan beberapa pendapat di atas, dapat disimpulkan bahwa model pembelajaran artikulasi merupakan model yang proses pembelajarannya siswa diminta untuk menyampaikan materi yang didapatkan dari guru kepada pasangannya secara bergiliran, siswa dibentuk menjadi kelompok kecil yang masing-masing siswa dalam kelompok tersebut mempunyai tugas mewawancarai teman kelompoknya tentang materi yang baru dibahas dan siswa dituntut untuk bisa berperan sebagai penerima pesan sekaligus berperan sebagai penyampai pesan.

Berdasarkan uraian di atas, maka peneliti akan mengadakan penelitian dengan judul, "Pengaruh Model Pembelajaran Artikulasi terhadap Kemampuan Menuliskan Kembali Pokok Pokok Berita yang Didengarkan Siswa 
Kelas VII SMP Negeri 2 Palembang". Berdasarkan latar belakang di atas, rumusan masalah dalam penelitian ini adalah bagaimanakah pengaruh model pembelajaran artikulasi terhadap kemampuan menuliskan kembali pokokpokok berita yang didengarkan siswa Kelas VII SMP Negeri 2 Palembang.

\section{B. METODOLOGI PENELITIAN}

Metode penelitian merupakan cara ilmiah untuk mendapatkan data dengan tujuan dan kegunaan tertentu (Sugiyono, 2015:3). Metode yang digunakan dalam penelitian ini adalah metode eksperimen kuantitatif. Dengan cara ini peneliti sengaja membangkitkan timbulnya suatu kejadian atau keadaan, kemudian diteliti bagaimana akibatnya.

Menurut Sukardi (2013:179), metode eksperimen merupakan salah satu bentuk penelitian yang memerlukan syarat yang relatif lebih ketat jika dibandingkan dengan jenis penelitian lainnya. Hal ini karena sesuai dengan maksud para peneliti yang mengiginkan adanya kepastian untuk memperoleh informasi tentang variabel mana yang menyebabkan sesuatu terjadi dan variabel yang memperoleh akibat dari terjadinya perubahan dalam suatu kondisi eksperimen.
Jenis eksperimen peneliti menggunakan pendekatan true experimental design (eksperimen yang betul-betul). Menurut Sugiyono (2015:113), dalam desain ini, peneliti dapat mengontrol semua variabel luar yang mempengaruhi jalannya eksperimen. Dengan demikian, validitas internal (kualitas pelaksanaan rancangan penelitian) dapat menjadi tinggi.

Ciri utama pendekatan true experimental design adalah bahwa sampel yang digunakan secara random dari populasi tertentu. Jadi, cirinya adalah adanya kelompok kontrol dan sampel dipilih secara random. Dalam true experimental design ada dua bentuk, yaitu Posttest-Only Control Design dan Pretest-Posttest Control Group Design. Dalam penelitian ini, peneliti memilih bentuk Posttest-Only Control Design, yaitu terdapat dua kelompok yang masing-masing dipilih secara random $(R)$. kelompok pertama diberikan perlakuan $(X)$ dan kelompok yang lain tidak. Kelompok yang diberikan perlakuan disebut kelompok eksperimen dan kelompok yang tidak diberikan perlakuan disebut kelompok kontrol dan pada akhirnya penelitian kedua kelompok dikenai posttest atau tes akhir.

Pengaruh adanya perlakuan (treatment) adalah $\left(O_{1}: O_{2}\right)$. Dalam penelitian, pengaruh treatment dianalisis dengan uji beda atau statistic t-test. Berikut 
ini adalah bentuk Posttest-Only Control Design:

\begin{tabular}{|ccc|}
\hline $\mathbf{R}$ & $\mathbf{X}$ & $\mathbf{O}_{2}$ \\
$\mathbf{R}$ & & $\mathbf{O}_{4}$ \\
\hline
\end{tabular}

Maksud dari desain tersebut adalah ada dua kelompok yang dipilih secara random. Kelompok pertama diberi perlakuan oleh peneliti kemudian dilakukan pengukuran, sedangkan kelompok kedua yang digunakan sebagai kelompok pengontrol tidak diberi perlakuan, tetapi hanya dilakukan pengukuran saja. Setelah perlakuan telah diberikan dalam jangka waktu tertentu, maka setelah itu dilakukan pengukuran variabel terikat pada kedua kelompok tersebut dan hasilnya dibandingkan perbedaannya.

Pada penelitian ini, peneliti mengambil sampel pada dua kelas, yaitu kelas VII B sebagai kelas ekperimen (kelas yang menggunakan model artikulasi di SMP Negeri 2 Palembang dan kelas VII C sebagai kelas kontrol (kelas yang menggunakan model artikulasi di SMP Negeri 2 Palembang

Populasi adalah wilayah generalisasi yang terdiri atas: obyek/subyek yang mempunyai kuantitas dan karakteristik tertentu yang ditetapkan oleh peneliti untuk dipelajari dan kemudian ditarik kesimpulannya (Sugiyono, 2015:119). Populasi penelitian ini adalah seluruh siswa kelas VII SMP Negeri 2 Palembang sebanyak 130 orang, yang terdiri atas 62 laki-laki dan 68 perempuan.

Sampel adalah bagian dari jumlah dan karakteristik yang dimiliki oleh populasi tersebut (Sugiyono, 2015:120). Sampel penelitian ini adalah sebagian dari siswa kelas VII SMP Negeri 2 Palembang.

Pengambilan sampel dalam penelitian ini menggunakan teknik random sampling, yaitu sebuah teknik sampel yang memberi hak yang sama kepada setiap subjek untuk memperoleh kesempatan (chance) dipilih menjadi sampel (Arikunto, 2013:177). Kemudian yang menjadi sampel dalam penelitian ini adalah kelas VII B dan VII C.

Langkah-langkah yang dilakukan untuk menganalisis data tes hasil belajar siswa adalah sebagai berikut.

1) Membuat kunci jawaban dan skor pada setiap masing-masing jawaban soal.

2) Memeriksa jawaban siswa.

3) Memeriksa skor dan hasil jawaban siswa sesuai dengan skor patokan yang telah ditentukan. 
4) Skor tes yang diperoleh masing-masing siswa dikonversikan menjadi Nilai Persentasi (NP).

$\mathrm{NP}=\frac{\text { Jumlah Skor }}{\text { Jumlah Skor Maksimum }} \times 100 \%$

Selanjutnya, untuk menentukan ratarata nilai siswa menggunakan rumus:

$\overline{\mathrm{x}}=\frac{\sum x i}{n}$

keterangan:

$\bar{x} \quad=$ Rata-rata nilai siswa

$\sum x i=$ Jumlah seluruh skor siswa

$\mathrm{n}$ = Banyaknya siswa

(Sudjana, 2005:67)

5) Langkah terakhir adalah dengan mengkonversikan hasil dari rata-rata nilai siswa ke data kualitatif untuk mengetahui hasil belajar siswa.

Uji normalitas berfungsi untuk mengetahui normal tidaknya penyebaran data. Uji normalitas perlu dilakukan untuk mengetahui apakah data yang dianalisis normal atau tidak, karena uji statistic parametris t atau uji-t baru dapat digunakan jika data terdistribusi secara normal.

Adapun langkah-langkah yang digunakan adalah sebagai berikut.

1) Menyusun data dalam tabel distribusi frekuensi.

a. Menghitung rentang kelas yaitu data terbesar dikurangi data terkecil.

$\mathrm{R}=X_{\text {maks }}-X_{\text {min }}$

Keterangan:
$\mathrm{R}=$ Range (daerah jangkauan data)

$X_{\text {maks }}=$ Data terbesar

$X_{\text {min }}=$ Data terkecil

b. Menghitung banyaknya kelas interval dengan menggunakan aturan sturgess dengan rumus:

$K=1+3,3 \log n$

(Sudjana, 2005:47)

Keterangan:

$\mathrm{K}=$ Banyak kelas

$\mathrm{n}=$ Bilangan kostanta

c. Menghitung panjang kelas interval $(P)$ dengan rumus:

$P=\frac{R}{K}$

(Sudjana, 2005:47)

Keterangan:

$P=$ Panjang kelas (interval kelas)

$\mathrm{R}=$ Range (daerah jangkauan data)

$\mathrm{K}=$ Banyak kelas

d. Membuat tabel data distribusi frekuensi

e. Menghitung nilai rata-rata dengan rumus:

$\overline{\mathrm{X}}=\frac{\sum f_{i x_{i}}}{\sum f_{i}}$

(Sudjana, 2005:67)

Keterangan:

$\overline{\mathrm{x}} \quad=$ Rata-rata

$f_{i}=$ Frekuensi yang

berhubungan dengan tanda kelas interval (Sudjana, 2Q05:47) = Tanda kelas interval 
f. Menghitung modus

$\mathrm{Mo}=\mathrm{b}+\mathrm{p}\left(\frac{b_{1}}{b_{1+} b_{2}}\right)$

Keterangan:

Mo $=$ Modus

$\mathrm{b}=$ Batas bawah kelas modus

$p=$ Panjang kelas interval

$b_{1}=$ Frekuensi kelas modus

dikurangi frekuensi sebelum kelas modus

$b_{2}=$ Frekuensi kelas modus dikurangi frekuensi setelah kelas modus

g. Menghitung simpangan baku dengan menggunakan rumus:

$S^{2}=\frac{n \sum f_{1} X_{1}^{2}-\left(f_{1} X_{1}\right)^{2}}{n(n-1)}$

Keterangan:

$S^{2}=$ Simpangan baku/standar deviasi

$\mathrm{n}$ = Banyak data

$f_{i}=$ Frekuensi sesuai dengan

tanda kelas interval

$x_{i}=$ Tanda kelas interval

h. Menghitung kenormalan data dengan koefesien kemiringan

$K_{m}=\frac{\bar{x}-M_{o}}{s}$

Keterangan:

$K_{m}=$ Kemiringan

$\bar{x}=$ Nilai rata-rata

Mo $=$ Modus

$\mathrm{S}=$ Simpangan baku/standar deviasi
Uji homogenitas dilakukan untuk

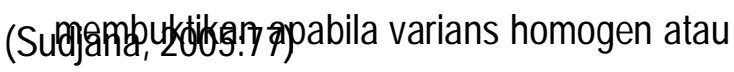
tidak. Pengujian homogenitas varians menggunakan uji $\mathrm{F}$ dengan rumus :

$$
F=\frac{\text { varian terbesar }}{\text { varian terkecil }}
$$$$
\text { (Sudjana, 2005:250) }
$$

Dengan kriteria pengujian homogenitas yaitu data dikatakan homogen jika fhitung $\leq f_{\text {tabel }}$ dan dalam hal lain data heterogen.

Setelah data terkumpul, dalam upaya membuktikan hipotesis yang telah dirumuskan dan untuk mendapatkan sesuatu kesimpulan maka hasil data tes

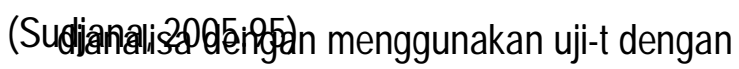
rumus sebagai berikut.

$$
\mathrm{t}=\frac{\bar{X}_{1}-\bar{X}_{2}}{s \sqrt{\frac{1}{n_{1}}+\frac{1}{n_{2}}}}
$$

(Sudjana, 2005:239)

Keterangan:

$\mathrm{t}=$ Nilai $\mathrm{t}_{\text {hitung }}$

$x_{1}=$ Nilai hasil belajar tes akhir kelompok eksperimen

$x_{2}=$ Nilai hasil belajar tes akhir

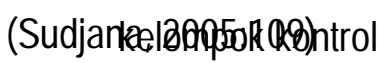

$\mathrm{n}_{1}=$ Jumlah sampel kelompok eksperimen

$\mathrm{n}_{2}=$ Jumlah sampel kelompok kontrol

$\mathrm{S}=$ Varians

Dimana: 
$s^{2}=\frac{\left(n_{1}-1\right) s_{1}^{2}+\left(n_{2}-1\right) s_{2}^{2}}{n_{1}+n_{2}-2}$

Keterangan:

$s^{1}=$ Simpangan baku siswa kelas eksperimen

$s^{2}=$ Simpangan baku siswa kelas kontrol

$\mathrm{n}_{1}=$ Sampel kelas eksperimen

$\mathrm{n}_{2}=$ Sampel kelas Kontrol

\section{HASIL DAN PEMBAHASAN}

Penelitian ini dilakukan pada dua kelas sampel. Dalam menentukan sampel, peneliti menggunakan teknik random sampling sehingga diperoleh kelas VII B (kelas eksperimen) dan kelas VII C (kelas kontrol). Kelas eksperimen diajarkan menggunakan model artikulasi, sedangkan kelas kontrol diajarkan dengan metode ceramah. Penelitian ini menggunakan metode eksperimen, sedangkan jenis eksperimen yang digunakan oleh peneliti adalah true experimental design dengan bentuk posttest-only control design. Pemilihan penggunaan metode tersebut bertujuan untuk membedakan kelas eksperimen dan kelas kontrol. Peneliti mengharapkan adanya perbedaan antara hasil belajar siswa kelas eksperimen dengan siswa kelas kontrol.

Hasil pembelajaran yang digunakan oleh peneliti dengan menggunakan model artikulasi di kelas VII B sebagai kelas eksperimen dapat dikatakan bahwa sebagian besar siswa dapat menerapkan model artikulasi dalam pembelajarannya. Hal ini dapat dilihat dari nilai rata-rata posttest yang didapatkan siswa kelas eksperimen, yaitu 74,5 sedangkan nilai ratarata siswa kelas VII C sebagai kelas kontrol, yaitu 63,1 .

Berdasarkan analisis data hasil tes kelas eksperimen yang menggunakan model artikulasi, dapat diketahui bahwa nilai rata-rata nilai posttest siswa kelas eksperimen yaitu kelas VIII B adalah 74,5 dengan nilai tertingginya adalah 90 yang diperoleh 1 orang siswa dan nilai terendahnya adalah 55 yang diperoleh 1 orang siswa. Sedangkan kelas VIII C sebagai kelas kontrol yang tidak menggunakan model artikulasi, dapat diketahui bahwa nilai rata-rata posttest siswa kelas kontrol adalah 63,1 dengan nilai tertingginya adalah 80 yang diperoleh 2 orang siswa dan nilai terendahnya adalah 45 yang diperoleh 1 orang siswa.

Berdasarkan data yang diperoleh dan diolah untuk mengetahui apakah hipotesis yang diajukan diterima atau ditolak, dengan menggunakan uji t sebagai penguji hipotesis yang diterapkan didapatkan harga $t_{\text {hitung }}=6,48$ sedangkan harga $t$ yang didapat dari $t_{\text {tabel }}=2,00$. Berdasarkan kriteria pengujian hipotesis, 
jika $t_{\text {hitung }}<t_{\text {tabel }}$ maka $\mathrm{H}_{0}$ diterima. Karena $t_{\text {hitung }}$ yang diperoleh lebih besar dari $t_{\text {tabel }}\left(t_{\text {hitung }}>t_{\text {tabel }}\right)$, maka tolak $\mathrm{H}_{0}$ dan terima $\mathrm{H}_{a}$. Artinya, model pembelajaran artikulasi mempengaruhi kemampuan siswa kelas VII SMP Negeri 2 Palembang dalam menulis pokok-pokok berita.

\section{SIMPULAN}

Berdasarkan hasil penelitian dan pembahasan yang telah dikemukakan pada bab sebelumnya, maka dapat disimpulkan bahwa nilai rata-rata pada kelas eksperimen setelah menggunakan model pembelajaran artikulasi adalah 74,5 dan nilai rata-rata kelas kontrol yang diajarkan menggunakan metode ceramah adalah 63,1. Hal ini menunjukkan bahwa belajar menggunakan model pembelajaran yang bervariasi dapat meningkatkan hasil belajar siswa.

Dari hasil analisis di atas, dapat disimpulkan bahwa ada pengaruh yang signifikan antara model pembelajaran artikulasi terhadap kemampuan menuliskan kembali pokok-pokok berita yang didengarkan siswa kelas VII SMP Negeri 2 Palembang.

\section{DAFTAR PUSTAKA}

Al-Tabany, Trianto Ibnu Badar. 2014. Mendesain Model Pembelajaran Inovatif, Progresif, dan Kontekstual. Jakarta: Prenadamedia Group.

Aqib, Zainal. 2015. Model-Model, Media dan Strategi Pembelajaran Kontekstual (Inovatif). Bandung: Yrama Widya.

Arikunto, Suharsimi. 2013. Prosedur Penelitian Suatu Pendekatan Praktik. Jakarta: Rineka Cipta. Chaer, Abdul. 2010. Bahasa Jurnalistik. Jakarta: Rineka Cipta.

Djamarah, Syaiful Bahri dan Zain, Aswan. 2013. Strategi Belajar Mengajar. Jakarta: Rineka Cipta.

Huda, Miftahul. 2014. Model-Model Pengajaran dan Pembelajaran. Yogyakarta: Pustaka Pelajar. Latuconsina, Chandra. 2014. Keterampilan Pers dan Jurnalistik. Universitas PGRI Palembang. Mudyahardjo, Redja. 2012. Pengantar Pendidikan. Jakarta: PT Raja Grafindo Persaja. Ngalimun. 2014. Strategi dan Model Pembelajaran. Yogyakarta: Aswaja Pressindo. Noor, Juliansyah. 2011. Metodologi Penelitian. Jakarta: Prenadamedia Group. 
Nugraheni, Aninditya Sri. 2012. Penerapan Strategi Cooperative Learning dalam Pembelajaran Bahasa Indonesia. Yogyakarta: Pedagogia.

Pristyan, Yoggy Bagus. 2016. Pengaruh Model Artikulasi dalam Kegiatan Mendeskripsikan Penggunaan Suatu Alat dengan Bahasa yang Baik dan Benar Kelas 4 SDN Sambitan 02 Kec. Pakel Tulungagung,(http://simki.unpkediri.ac.id/mahasiswa/file artikel/2016/11.1.01. 10.0380.pdf, diakses 17 Maret 2016).

Rosidi, Imron. 2009. Menulis Siapa Takut. Yogyakarta: Kanisius.

Shoimin, Aris. 2014. Model Pembelajaran Inovatif dalam Kurikulum 2013. Yogyakarta: Ar-Ruzz Media.

Sudjana. 2005. Metoda Statistika. Bandung: Tarsito.

Sugiyono. 2015. Metode Penelitian Kombinasi (Mixed Methods). Bandung: Alfabeta.

Sukardi. 2013. Metodologi Penelitian Pendidikan Kompetensi dan Praktiknya. Yogyakarta: Bumi Aksara.

Tarigan, Henry Guntur. 2008. Menulis Sebagai Suatu Keterampilan Berbahasa. Bandung: Angkasa.

Uno, Hamzah B. dan Mohamad, Nurdin. 2013. Belajar dengan Pendekatan Pembelajaran Aktif Inovatif Lingkungan Kreatif Efektif Menarik. Jakarta: Bumi Aksara.

Wardarita, Ratu. 2014. Kajian Bahasa dan Sastra Indonesia. Yogyakarta: Elmatera. 